\title{
Correction Alternative mechanisms of miR-34a regulation in cancer
}

Eva Slabáková', Zoran Culig ${ }^{2,3}$, Ján Remšík ${ }^{1,2,4}$ and Karel Souček ${ }^{1,2,4}$

Correction to: Cell Death \& Disease; https://doi.org/ 10.1038/cddis.2017.495; published online 12 Oct 2017.
The PDF and HTML versions of the article have been updated to include the Creative Commons Attribution 4.0 International License information.

Published online: 16 July 2018

Correspondence: Eva Slabáková (slabakova@ibp.cz) or

Karel Souček (ksoucek@ibp.cz)

${ }^{1}$ Department of Cytokinetics, Institute of Biophysics of the Czech Academy of Sciences, Brno, Czech Republic

${ }^{2}$ Center of Biomolecular and Cellular Engineering, International Clinical

Research Center, St. Anne's University Hospital Brno, Brno, Czech Republic

${ }^{3}$ Division of Experimental Urology, Department of Urology, Medical University

of Innsbruck, Innsbruck, Austria

${ }^{4}$ Department of Experimental Biology, Faculty of Science, Masaryk University,

Brno, Czech Republic

(c) The Author(s) 2018

(c) (i) Open Access This article is licensed under a Creative Commons Attribution 4.0 International License, which permits use, sharing, adaptation, distribution and reproduction in any medium or format, as long as you give appropriate credit to the original author(s) and the source, provide a link to the Creative Commons license, and indicate if changes were made. The images or other third party material in this article are included in the article's Creative Commons license, unless indicated otherwise in a credit line to the material. If material is not included in the article's Creative Commons license and your intended use is not permitted by statutory regulation or exceeds the permitted use, you will need to obtain permission directly from the copyright holder. To view a copy of this license, visit http://creativecommons.org/licenses/by/4.0/. 